\title{
Variations in Codons 84-101 in the Core Nucleotide Sequence Correlate with Hepatocellular Injury in Chronic Hepatitis B Virus Infection
}

Toshiki Ehata, Masao Omata, Osamu Yokosuka, Kazuhiko Hosoda, and Masao Ohto

First Department of Medicine, Chiba University School of Medicine, Chiba 280, Japan

\begin{abstract}
Individuals with chronic hepatitis B virus (HBV) infection are generally divided into asymptomatic healthy carriers and patients with chronic liver disease. Several studies have suggested that the hepatitis $B$ core antigen could be an immunological target of cytotoxic T lymphocytes (CTL). To investigate the possible pressure site from $\mathrm{CTL}$, the entire core region of $\mathrm{HBV}$ DNA was sequenced in 30 subjects (10 asymptomatic healthy carriers and 20 patients with chronic liver disease). No significant changes in the nucleotide sequence and deduced amino acid residue were noted in the 10 healthy carriers. In contrast, a cluster of changes in a small segment of 18 amino acids (codons 84-101 from the start of the core gene) was found in 15 of the 20 chronic liver disease patients. All these 15 patients had advanced liver diseases (chronic active hepatitis and cirrhosis), whereas only mild liver disease (chronic persistent hepatitis) was found in the five patients without mutations. These data suggest that the region with mutation clustering is the major target of CTL, and that the mutations evolve under the pressure of immune selection. (J. Clin. Invest. 1991. 89:332-338.) Key words: asymptomatic carrier • cytotoxic $\mathbf{T}$ cell $\bullet$ hepatitis $B$ core - mutation • polymerase chain reaction
\end{abstract}

\section{Introduction}

Individuals infected with the hepatitis B virus (HBV) ${ }^{1}$ could be divided into two groups: one with no liver disease (asymptomatic healthy carriers) and the other with continuous liver injury. Previous studies have suggested that the hepatic injury due to $\mathrm{HBV}$ is immune-mediated, and that the hepatitis B core antigen $(\mathrm{HBcAg})$ could be an immunological target (1-5). HBV DNA contains four open reading frames, one of them

Address reprint requests to Dr. Omata, First Department of Medicine, Chiba University School of Medicine, 1-8-1 Inohana, Chiba 280, Japan.

Received for publication 21 June 1991 and in revised form 17 September 1991.

1. Abbreviations used in this paper: ALT, alanine aminotransferase; CTL, cytotoxic T lymphocyte; $\mathrm{HBcAg}, \mathrm{HBeAg}$, and $\mathrm{HBsAg}$, hepatitis $B$ core, e, and surface antigens, respectively; HBV, hepatitis B virus; PCR, polymerase chain reaction; pre-C, precore (region).

J. Clin. Invest.

(c) The American Society for Clinical Investigation, Inc.

0021-9738/92/01/0332/07 \$2.00

Volume 89, January 1992, 332-338 being the $\mathrm{C}$ gene coding for a core peptide ( $\mathrm{HBcAg})(6)$. The $\mathrm{C}$ gene encodes 183-185 amino acid residues of a nucleocapsid protein, and is preceded by the precore (pre-C) region starting with an initiation codon and encoding 29 amino acid residues (6).

Recent studies on endogenously processed viral peptides have revealed that a peptide as small as eight amino acids could be recognized by cytotoxic T lymphocytes $(C T L)(7,8)$. Thus, we have postulated that if there is "pressure" from CTL, one may be able to find substitutions in amino acid residues in a restricted segment of the core gene. Changes in such a region may help to predict the outcome of B-viral liver disease. We randomly selected 10 asymptomatic healthy carriers with no abnormal liver function tests for 3-8 yr and 20 patients suffering from chronic liver disease with fluctuating serum alanine aminotransferase (ALT) levels. The nucleotide sequence of the entire core gene was determined in these 30 subjects by the polymerase chain reaction (PCR) and direct sequencing methods (9-11).

\section{Methods}

\section{Patients}

Sera were taken from 30 persistently hepatitis B surface antigen (HBsAg)-positive patients who were followed at the First Department of Medicine, Chiba University, at least for $3 \mathrm{yr}$. Subtypes of HBsAg of these patients were all adr.

Group A (asymptomatic healthy carriers). There were 10 hepatitis B e antigen ( $\mathrm{HBeAg}$ )-positive asymptomatic carriers. They showed serum ALT levels within an almost normal range by regular examinations every 1-2 mo for 3-8 yr. Liver biopsy was performed in five of these subjects, and only mild histological changes (chronic persistent hepatitis in two and nonspecific changes in three) were found (Table I).

Group B (chronic liver diseases). 20 patients with fluctuating liver enzymes were studied. 16 of them (patients 11-26 in Table I) had HBeAg-positive chronic liver disease with fluctuating ALT levels for 3-10 yr. Liver biopsy was performed in 14 of these patients, and chronic persistent hepatitis was found in four, chronic active hepatitis in nine, and cirrhosis of the liver in one.

Four patients (nos. 27-30 in Table I) had hepatitis B e antibody $(\mathrm{HBe} A b)$-positive chronic liver diseases with fluctuating ALT levels for 6-11 yr. All had liver biopsy and the histological diagnosis was chronic active hepatitis in three patients and cirrhosis of the liver in one.

\section{$H B V$ markers}

$\mathrm{HBs} \mathrm{Ag}$ and $\mathrm{HBeAg}$ - $\mathrm{Ab}$ were assayed using solid-phase radioimmunoassay (Abbott Laboratories, North Chicago, IL). Antihepatitis $C$ virus antibody was measured by enzyme immunoassay (Ortho Diagnostics, Tokyo, Japan). All the samples were negative for anti-hepatitis $\mathrm{C}$ virus antibody. 
Table I. Clinical and Laboratory Data on 10 Asymptomatic Healthy Carriers and 20 Patients with Fluctuating Serum ALT Levels and Chronic Liver Diseases

\begin{tabular}{|c|c|c|c|c|c|c|c|}
\hline \multirow[b]{2}{*}{ Age/Sex } & \multicolumn{2}{|c|}{$\mathrm{ALT}$} & \multirow[b]{2}{*}{ Follow-up } & \multirow[b]{2}{*}{$\mathrm{HBeAg} / \mathrm{Ab}^{*}$} & \multirow[b]{2}{*}{$\begin{array}{l}\text { Mutation } \\
\text { in codons } \\
(84-101)^{ \pm}\end{array}$} & \multirow[b]{2}{*}{$\begin{array}{c}\text { Liver } \\
\text { histology }\end{array}$} & \multirow[b]{2}{*}{$\begin{array}{c}\text { Pre-C } \\
\text { mutation }\end{array}$} \\
\hline & $\begin{array}{c}\text { Values } \\
\text { at sampling* }\end{array}$ & Mean/Range & & & & & \\
\hline
\end{tabular}

Group A (asymptomatic carriers)

$\begin{array}{ll}\text { 1. } 27 / \mathrm{F} & 17 \\ 2.39 / \mathrm{F} & 17 \\ \text { 3. } 48 / \mathrm{M} & 22 \\ \text { 4. } 20 / \mathrm{M} & 34 \\ \text { 5. } 24 / \mathrm{M} & 29 \\ 6.26 / \mathrm{M} & 31 \\ \text { 7. } 21 / \mathrm{F} & 19 \\ 8.41 / \mathrm{M} & 22 \\ \text { 9. } 30 / \mathrm{F} & 34 \\ 10.17 / \mathrm{F} & 18\end{array}$

$\begin{array}{ll}17 & 19.2 / 7-47 \\ 17 & 23.1 / 17-43 \\ 22 & 28.0 / 21-39 \\ 34 & 32.6 / 19-54 \\ 29 & 44.3 / 24-62 \\ 31 & 27.7 / 16-44 \\ 19 & 22.1 / 13-27 \\ 22 & 30.3 / 19-54 \\ 34 & 28.2 / 18-46 \\ 18 & 22.1 / 18-30\end{array}$

Group B (patients with liver disease)

$\begin{array}{lrc}11.43 / \mathrm{M} & 278 & 148.5 / 23-1,750 \\ 12.49 / \mathrm{F} & 126 & 68.9 / 39-126 \\ 13.30 / \mathrm{M} & 107 & 155.7 / 48-257 \\ 14.52 / \mathrm{F} & 337 & 92.0 / 10-337 \\ 15.40 / \mathrm{F} & 131 & 143.0 / 28-576 \\ 16.38 / \mathrm{M} & 395 & 139.9 / 23-831 \\ 17.38 / \mathrm{M} & 86 & 115.9 / 26-602 \\ 18.35 / \mathrm{M} & 110 & 109.8 / 33-306 \\ 19.42 / \mathrm{M} & 114 & 115.1 / 22-595 \\ 20.26 / \mathrm{F} & 418 & 92.0 / 9-418 \\ 21.29 / \mathrm{F} & 537 & 78.1 / 17-537 \\ 22.41 / \mathrm{M} & 131 & 102.4 / 22-596 \\ 23.31 / \mathrm{M} & 846 & 134.3 / 13-846 \\ 24.24 / \mathrm{M} & 849 & 196.9 / 9-849 \\ 25.22 / \mathrm{M} & 833 & 127.1 / 19-833 \\ 26.42 / \mathrm{M} & 503 & 205.6 / 17-1,578 \\ 27.46 / \mathrm{M} & 251 & 103.4 / 21-578 \\ 28.26 / \mathrm{M} & 588 & 101.6 / 8-615 \\ 29.31 / \mathrm{M} & 463 & 81.8 / 28-583 \\ 30.30 / \mathrm{M} & 598 & 143.6 / 26-1,288\end{array}$

Abbreviations: $\mathrm{CAH}$, chronic active hepatitis; $\mathrm{CPH}$, chronic persistent hepatitis; LC, cirrhosis of the liver; ND, not done; NSC, nonspecific changes. ${ }^{*}$ Values or results when core gene nucleotide sequences were studied. ${ }^{\ddagger}$ Change in the number of codons from the start of $\mathrm{C}$ gene.

\section{Amplification and sequencing of the core and precore region of $H B V D N A$}

To amplify the C gene of HBV DNA (549-555 nucleotides or 183-185 amino acid residues), we prepared several sets of synthetic oligonucleotide primers according to the reported sequence of adr subtype by Kobayashi et al. (12) (Fig. 1): sense primers-F1 (nucleotides [nt] 1618-1635, 5'-GGGAGGAGATTAGGTTAA-3'), F2 (nt 1518-1537, 5'-AAGCTCTTACATAAGAGGAC-3'); antisense primers-F3 (nt 2328-2347, 5'-ACCTTATGAGTCCAAGGGAT-3'), F4 (nt 2363-2382, 5'GTACAGTAGAAGAATAAAGC-3'). By these primers, a segment of HBV DNA spanning 865 nucleotides from 1518 to 2382 , which comprises the entire precore and core region, was amplified by PCR (9). These primers were synthesized by the phosphoramidite method. Amplification of HBV DNA was performed basically by the method described previously (10). Briefly, 100- $\mu \mathrm{l}$ reaction mixtures containing $10 \mu \mathrm{l}$ of specimen DNA, $50 \mathrm{mM} \mathrm{KCl}, 10 \mathrm{mM}$ Tris- $\mathrm{HCl}$ (pH 8.4), $2.5 \mathrm{mM} \mathrm{MgCl}_{2}$, $1 \mu \mathrm{M}$ each of the two oligonucleotide primers, $200 \mu \mathrm{M} \mathrm{dNTP \text {, }}$ $200 \mu \mathrm{g} / \mathrm{ml}$ of gelatin, and $2 \mathrm{U}$ of Thermus aquaticus DNA polymerase were overlaid with $100 \mu$ l of mineral oil. Samples were heated at $95^{\circ} \mathrm{C}$ for $2 \mathrm{~min}$ (denaturation), cooled to $50^{\circ} \mathrm{C}$ for $2 \mathrm{~min}$ (annealing), and heated to $70^{\circ} \mathrm{C}$ for $2 \mathrm{~min}$ (extension). These steps were repeated for $30-50$ cycles. After the final step of amplification, each sample $(10 \mu \mathrm{l})$ was applied to an $8 \%$ acrylamide gel. For direct sequencing of a portion of HBV DNA, the PCR products were centrifuged in microconcentrators (Centricon 30, Amicon Corp., Danvers, MA). To 


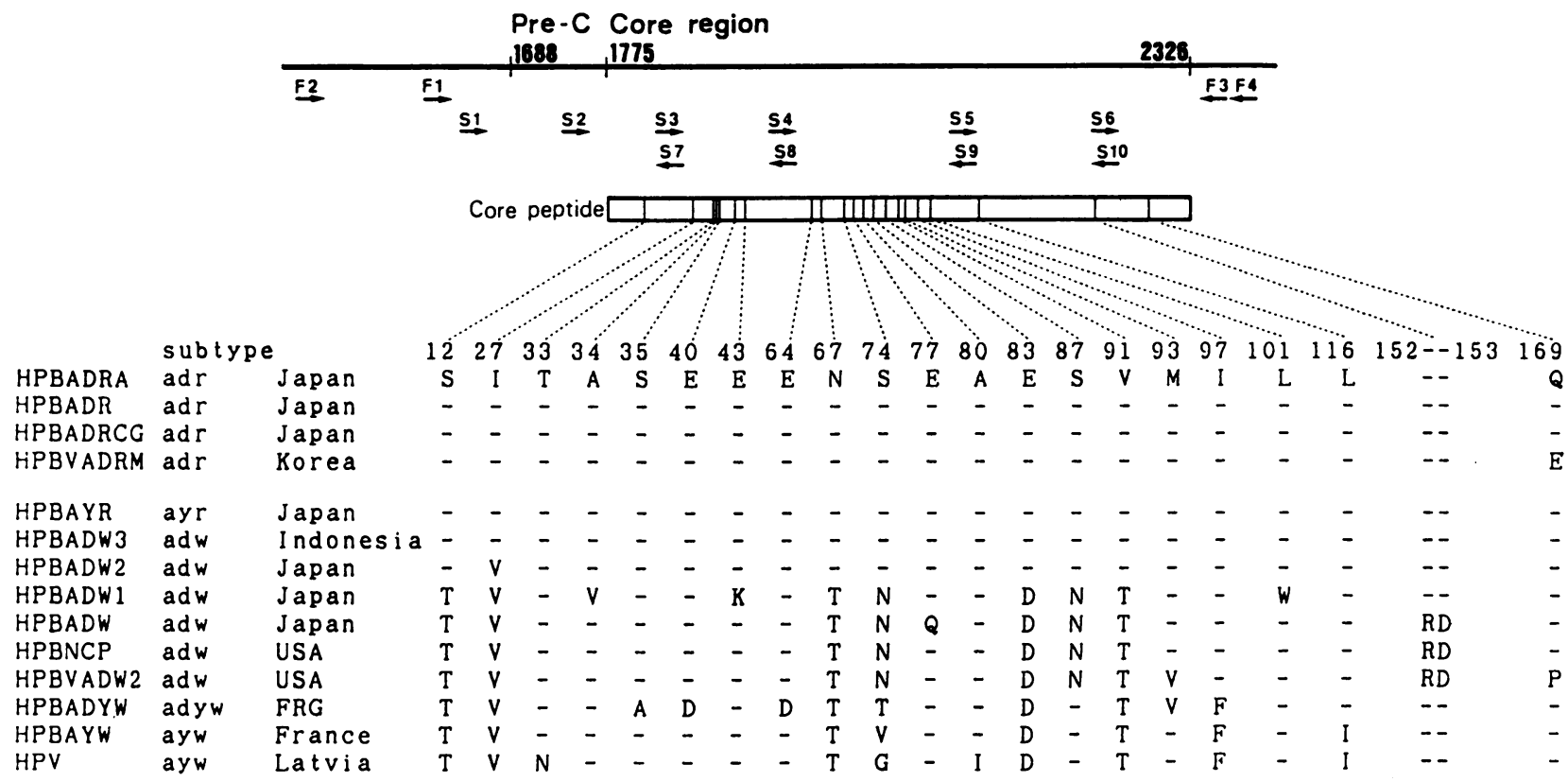

Figure 1. Schematic presentation of the core peptide of HBV. Locations of amplification and sequencing primers used for PCR and direct sequencing are shown by arrows. Sense amplification primers, F1 and F2; antisense amplification primers, F3 and F4. Sense sequencing primers, S1-S6; antisense sequencing primers, S7-S10. Nucleotide sequences of these primers are described in the text. Deduced amino acid residues of the core peptide, different from prototype adr (12), are plotted against the corresponding position of the core peptide. Amino acid residues are numbered from start of core gene. The dashed line indicates the same amino acid as that reported by Kobayashi et al. (12). $152 \mathrm{R} \mathrm{D} \mathrm{153} \mathrm{means}$ an insertion of two amino acid residues which are arginine $(R)$ and aspartic acid (D) between the 152th and 153th codon of the prototype. Abbreviations: A, alanine; C, cysteine; D, aspartic acid; E, glutamic acid; F, phenylalanine; G, glycine; H, histidine; I, isoleucine; K, lysine; L, leucine; $\mathrm{M}$, methionine; $\mathrm{N}$, asparagine; $\mathrm{P}$, proline; $\mathrm{Q}$, glutamine; $\mathrm{R}$, arginine; $\mathrm{S}$, serine; $\mathrm{T}$, threonine; $\mathrm{V}$, valine; $\mathrm{W}$, tryptophan; $\mathrm{Y}$, tyrosine. Quoted references are as follows: HPBADRA (12); HPBADR (13); HPBADRCG (14); HPVADRM (15); HPBAYR (16); HPBADW3 (17); HPBADW2 (17); HPBADW1 (17); HPBADW (13); HPBNCP (18); HPBVADW2 (19); HPBADYW (20); HPBAYW (21); HPV (22).

sequence the amplified segment bidirectionally, we prepared several sequencing primers: sense primers-S1 (nt 1644-1662, 5'-GTACTAGGAGGCTGTAGGC-3'), S2 (nt 1739-1758, 5'CAAGCCTCCAAGCTGTGCCT-3'), S3 (nt 1828-1847, 5'TTTGCCTTCTGACTTCTTTC-3'), S4 (nt 1934-1953, 5'GCACTCAGGCAAGCTATTCT-3'), S5 (nt 2103-2121, 5'TTGGAAGAGAAACTGTTCT-3'), S6 (nt 2228-2247, 5'-CGAGGCAGGTCCCCTAGAAG-3'); antisense primersS7 (nt 1828-1847, 5'-GAAAGAAGTCAGAAGGCAAA-3'), S8 (nt 1934-1953, 5'-AGAATAGCTTGCCTGAGTGC-3'), S9 (nt 2103-2121, 5'-AGAACAGTTTCTCTTCCAA-3'), S10 (nt 2228-2247, 5'-CTTCTAGGGGACCTGCCTCG-3').

One sequencing primer was radiolabeled with $\left[{ }^{32} \mathrm{P}\right] \mathrm{ATP}$ and T4 polynucleotide kinase. From 1 to $10 \mathrm{pmol}$ of microconcentrator-purified PCR product and 5 pmol of ${ }^{32} \mathrm{P}$-labeled sequencing primer were combined in $12 \mu \mathrm{l}$ of $50 \mathrm{mM} \mathrm{KCl}, 50$ $\mathrm{mM}$ Tris (pH 8.0), $5 \mathrm{mM} \mathrm{MgCl}_{2}$, and $10 \mathrm{mM}$ dithiothreitol. The direct sequencing of the PCR products was performed as previously described (11).

\section{Results}

Changes of serum ALT levels. Serial changes of serum ALT levels in 10 asymptomatic healthy carriers (group A) and 20 patients with chronic liver disease (group B) are shown in Fig. 2. Serum ALT levels were within nearly normal range for 3-8 $\mathrm{yr}$ in the healthy carriers despite active virus replication (all patients were seropositive for $\mathrm{HBeAg}$ ). In contrast, in the chronic liver disease group serum enzyme levels continuously fluctuated (Fig. 2).

Nucleotide sequence and deduced amino acid residue of core gene. The entire nucleotide sequence of the core gene of HBV was obtained in all 30 patients. Different nucleotides from the adr sequence reported by Kobayashi et al. (12) were found at 185 locations (49 nucleotides in group $A$ and 136 in group B). Of these 185 nucleotide substitutions, 146 were "silent" (without changes in the deduced amino acid residue) and 39 were "missense" (with alterations in the deduced amino acid residue). All 49 nucleotide changes observed in group A were "silent," and all the 10 patients showed amino acid residues identical to those reported by Kobayashi et al. (12) (Fig. 3).

In contrast, all the 39 "missense" nucleotide changes were found in group B. The 39 deduced amino acid substitutions are given in Fig. 3. Of these changes, $21(54 \%)$ clustered in a small segment of 18 amino acids (codons 84-101 from the start of the core gene, $9.8 \%$ of the entire 183 amino acids) (Fig. 3). At least one amino acid substitution in this segment was found in 15 of the 20 chronic liver disease patients (Table I) (Fig. 3). Of these 15,14 had amino acid substitutions restricted to a smaller segment of 11 amino acid residues (codons 87-97) (Fig. 3). Of interest was the finding that advanced liver disease (chronic active hepatitis and cirrhosis) was seen in these 15 patients with amino acid residue substitutions in this "hypervariable" region, whereas all five patients without such substitutions had only mild liver disease (chronic persistent hepatitis) (Table I). 

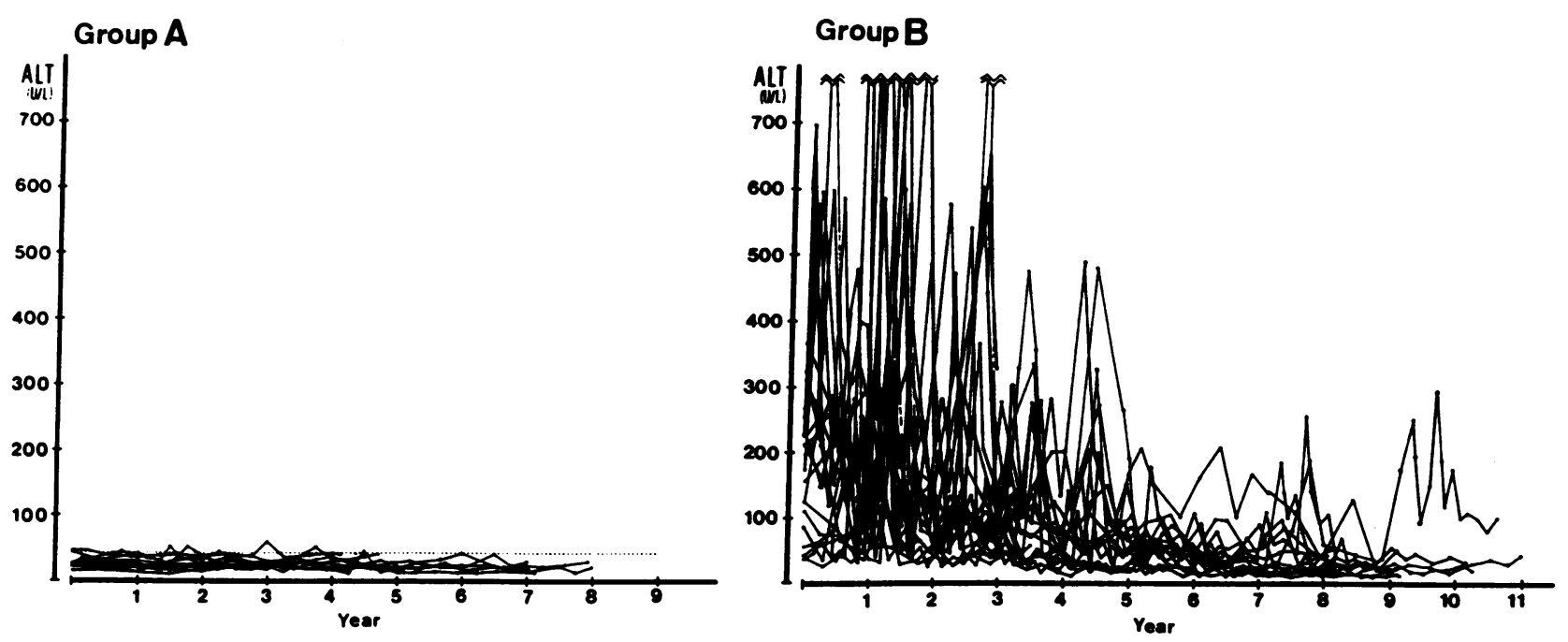

Figure 2. Changes of serum ALT values in 10 asymptomatic carriers (group A) and in 20 patients with liver disease (group B).

Core Codon

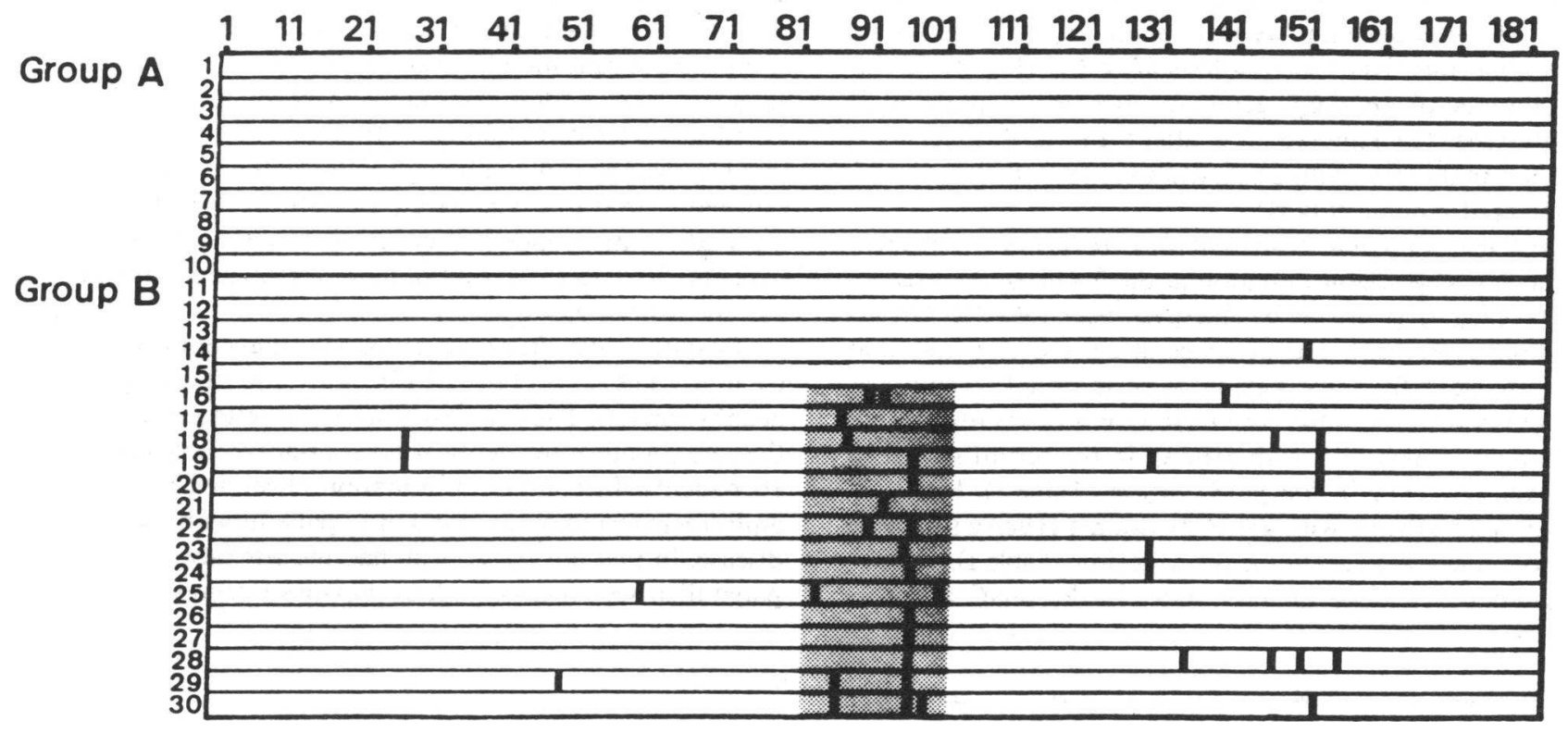

\begin{tabular}{|c|c|c|c|c|c|c|c|c|c|c|c|c|c|c|c|c|c|c|c|c|}
\hline Core Co & $10 n$ & $\begin{array}{c}27 \\
1\end{array}$ & $\begin{array}{l}49 \\
\mathrm{~S}\end{array}$ & 60 & 84 & $\begin{array}{l}87 \\
S\end{array}$ & $\begin{array}{l}88 \\
Y\end{array}$ & $\begin{array}{l}91 \\
\mathrm{Y}\end{array}$ & 93 & 96 & 97 & 99 & 101 & $\begin{array}{c}130 \\
P\end{array}$ & $\begin{array}{c}135 \\
P\end{array}$ & $\begin{array}{c}140 \\
\text { L }\end{array}$ & $\begin{array}{c}147 \\
T\end{array}$ & $\begin{array}{c}151 \\
R\end{array}$ & 153 & $\begin{array}{c}156 \\
P\end{array}$ \\
\hline Pationt & 14 & 1 & - & - & - & - & - & - & - & $\underline{-}$ & - & - & - & P & 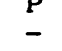 & 2 & - & $\begin{array}{l}k \\
C\end{array}$ & $\underline{-}$ & P \\
\hline & 16 & - & - & - & - & - & - & $\underline{A}$ & $I$ & - & - & - & - & - & - & I & - & - & - & - \\
\hline & 17 & - & - & - & - & $\underline{G}$ & - & $=$ & $\overline{-}$ & - & - & - & - & - & - & - & - & - & - & - \\
\hline & 18 & V & - & - & - & $\overline{-}$ & $\underline{H}$ & - & - & - & - & - & - & $\overline{-}$ & - & - & $\mathbf{A}$ & - & C & - \\
\hline & 19 & $\underline{\mathbf{V}}$ & - & - & - & - & $=$ & - & - & - & $\underline{L}$ & - & - & $\mathbf{T}$ & - & - & - & - & C & - \\
\hline & 20 & - & - & - & - & - & - & - & $\overline{-}$ & - & $\bar{L}$ & - & - & - & - & - & - & - & $\underline{\bar{C}}$ & - \\
\hline & 21 & - & - & - & - & - & - & - & $\underline{I}$ & - & $=$ & - & - & - & - & - & - & - & $\overline{\bar{Z}}$ & - \\
\hline & 22 & - & - & - & - & - & - & $\underline{A}$ & - & - & $\underline{L}$ & - & - & - & - & - & - & - & - & - \\
\hline & 23 & - & - & - & - & - & - & - & - & $\underline{\mathbf{N}}$ & $=$ & - & - & $T$ & - & - & - & - & - & - \\
\hline & 24 & - & - & - & - & - & - & - & - & $\overline{=}$ & $\mathbf{L}$ & - & - & $\mathbf{Q}$ & - & - & - & - & - & - \\
\hline & 25 & - & - & $\mathbf{V}$ & $\mathbf{V}$ & - & - & - & - & - & $=$ & - & $I$ & - & - & - & - & - & - & - \\
\hline & 26 & - & - & - & - & - & - & - & - & - & $\underline{L}$ & - & - & - & - & - & - & - & - & - \\
\hline & 27 & - & - & - & - & - & - & - & - & - & $\underline{\mathbf{L}}$ & - & - & - & - & - & - & - & - & - \\
\hline & 28 & - & $\bar{z}$ & - & - & $\overline{-}$ & - & - & - & - & $\underline{L}$ & - & - & - & $\mathbf{S}$ & - & C & $\mathbf{Q}$ & - & $\mathbf{S}$ \\
\hline & 2 & - & $\mathrm{T}$ & - & - & G & - & - & - & - & $\overline{\mathbf{L}}$ & - & - & - & - & - & - & - & - & - \\
\hline & 30 & - & - & - & - & G & - & - & - & - & $\mathbf{L}$ & $\mathbf{R}$ & - & - & - & - & - & - & C & - \\
\hline
\end{tabular}

Figure 3. Deduced amino acid residues of core peptide in 30 patients. (Top) Only the deduced amino acid residues different from the prototype reported by Kobayashi et al. (12) are indicated by vertical solid lines. 39 locations were noted. The "hypervariable" region from codon 84 to codon 101 is shaded. (Bottom) All changes of amino acid residues different from the prototype (12) are shown. Codon numbers and prototype amino acid sequence are given in the top two rows. Dashes indicate

identity of the prototype. Core codons are numbered from the beginning of the core region. Amino acid residues are expressed by single letters (see the legend for Fig. 1). The underlined amino acid residues indicate coexistence of prototype sequence. 
At other locations in the core peptide, 14 amino acid substitutions were found in a 27-amino acid segment from 130 to 156 (Fig. 3). Sporadic amino acid substitutions were recognized in codons 27, 49, and 60 (Fig. 3).

Comparison with reported amino acid residues of core region. 14 previously reported amino acid residues of the core region of $\mathrm{HBV}$ are aligned in Fig. 1 according to their subtypes (12-22). Four sequences with the adr subtype showed well-conserved amino acid residues of core peptides (Fig. 1). In contrast, HBV with a "w" determinant seems to have somewhat different sequences (Fig. 1). We plotted the codons which showed amino acid residues different from the prototype adr sequence (12) against the corresponding positions of the core peptide (Fig. 1). It appears that there is a "hypervariable" region of codons 74-101 where frequent variations occur in amino acid residues (Fig. 1). The region of codons 84-101 where mutations clustered in our patients was located in this segment. However, the substitutions found in our patients ( $\mathrm{L}$ to $\mathrm{V}$ at $84, \mathrm{~S}$ to $\mathrm{G}$ at $87, \mathrm{Y}$ to $\mathrm{H}$ at $88, \mathrm{~V}$ to $\mathrm{A}$ at $91, \mathrm{M}$ to $\mathrm{T}$ at $93, \mathrm{I}$ to $\mathrm{L}$ at $97, \mathrm{~L}$ to $I$ at 101) were not identified in any of the 14 reported sequences (Fig. 1) (12-22). Thus, the changes in our patients may be de novo substitutions.

To study further whether these changes in amino acid residues were in fact "de novo," we tested serial samples from one patient who was once an "asymptomatic carrier," but began having abnormal liver function tests after $3 \mathrm{yr}$ (Fig. 4). In the asymptomatic phase, the $C$ gene sequence was identical with the prototype (12). However, $2 \mathrm{yr}$ after the start of rise of ALT levels, a mutant virus with a substitution of I to $\mathrm{L}$ at codon 97 became predominant (Fig. 4).

Pre-C mutation and changes in the core region. A defective virus with a stop codon mutation at the $3^{\prime}$-end of the precore region incapable of encoding $\mathrm{HBeAg}$ has been found in various liver diseases (23-25). The presence of a pre-C stop codon at the 28th codon from the beginning of the pre- $\mathrm{C}$ region was analyzed in relation to the core region in our patients. All but one patient (patient 17) with $\mathrm{HBeAg}$ in the serum showed a prototype sequence in the pre-C region (Table I). However, three of four patients with antibody against $\mathrm{HBeAg}$ showed a stop codon at codon 28 in the pre-C region (Table I).

Sequential changes of nucleotides in the pre- $\mathrm{C}$ and core region studied in one patient suggested that the amino acid residue change in the "hypervariable" region (isoleucine to leucine at codon 97 in the core region) preceded the appearance of a stop codon in the precore region by $\sim 3$ yr (Fig. 4 ).

These data suggested that viruses with a mutation in the hypervariable region of the core peptide might induce a stop codon at the 3 '-end of the hydrophobic domain of the pre-C polypeptide to cease further secretion of the modified nucleocapsid peptide.

\section{Discussion}

It is not known why there are differences in the severity of liver disease among HBV-infected individuals (26). Previous studies focused primarily on host factors. For example, an attempt was made to define a relation between B-viral liver disease and the HLA system (27).

Advanced molecular biological technology has permitted us to analyze virus nucleotide sequences in 30 patients with various liver diseases. We decided to analyze the $\mathrm{C}$ gene of $\mathrm{HBV}$, because it was previously suggested that the core peptide ( $\mathrm{HBcAg}$ ) could be an immunological target of cytotoxic $\mathrm{T}$ cells in HBV infection (2-5). It was recently shown that hyperimmune globulin against $\mathrm{HBsAg}$ may force the antigenic epitope of "a" determinant of surface antigen to mutate (28). An amino acid substitution from glycine to arginine at the strongly antigenic 145th codon from the start of the surface gene was found in vaccinated children (28). Thus, we have postulated that the virus gene may undergo changes as a result of various exogenous pressures. The selective pressure might be found by the study of nucleotide sequences of the core gene in various patients. We selected asymptomatic carriers and patients with chronic liver diseases.

Despite active virus replication, no significant hepatocellular injury has been observed for 3-8 yr in 10 asymptomatic healthy carriers. The deduced amino acid residue sequences of the core peptide were identical to the prototype sequences in all 10 patients. In contrast, a mutation clustering region of 18 amino acid residues was found in 15 patients with chronic liver disease. In that our patients all had the adr subtype, we compared their sequences with four previously reported ones (12-

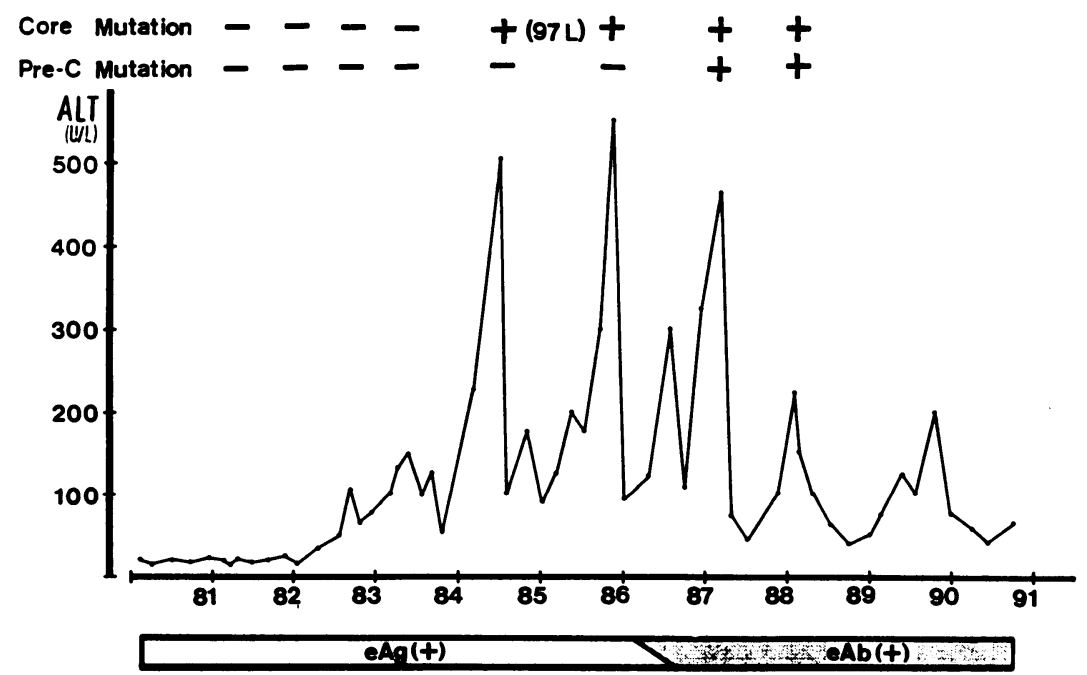

Figure 4. The clinical course of a 41 -yr-old female patient who was an asymptomatic carrier at the beginning, but began having continuous fluctuation of serum ALT levels. Core mutation indicates the appearance of deduced amino acid residue change at codon 97 of core peptide from isoleucine (I) to leucine (L), and pre-C mutation indicates the appearance of a stop codon mutation at the 28 th codon of the precore region. 
15). A striking conservation of 183 amino acid residues of the core peptide was demonstrated in the adr subtype. In all those reports, blood samples were obtained from asymptomatic healthy carriers (12-15). The localization of the mutation clustering region in our 15 patients was striking in several aspects. It was mostly restricted to only a small segment of the gene (codon 84-101). The region was as small as 11 amino acid residues (from 87 to 97 ) in 14 of the 15 patients. No such amino acid substitution in this region has been reported previously in adr nor in other subtypes (12-22). The rate of evolution of the $\mathrm{HBV}$ core gene has been estimated previously as $2.2 \times 10^{-5}$ per nucleotide per year in an asymptomatic carrier (29). Thus, it is expected to take at least $80 \mathrm{yr}$ to have a nucleotide substitution in the entire core gene in asymptomatic carriers. However, a nucleotide substitution was observed in the cluster region found in this study in only $5 \mathrm{yr}$ of follow-up observation in an asymptomatic patient who later developed abnormal liver function tests (Fig. 4). Thus, the mutation clustering region could be a hot spot for mutations related to the development of B-viral liver disease.

Recent studies of influenza and vascular stomatitis viruses indicate that the targets of CTL are endogenously processed viral peptides derived from nucleocapsid proteins which are as small as $8-10$ amino acid residues $(7,8)$. Thus, it is tempting to speculate that the mutation clustering region found only in patients with hepatic injury could be an immunological target of CTL. Milich et al. (30) indicated in H-2 mouse that one of the $\mathrm{T}$ cell sites was located in the synthetic peptide of codons 85-100. Furthermore, a recent study on amino acid sequences eluted from MHC molecules revealed that mouse $\mathrm{K}^{\mathrm{d}}$-restricted peptide anchor motif was Y------I/L and that of human HLAA2 was $\mathrm{L} / \mathrm{M}-.-.--\mathrm{V}$ (31). These motifs were seen in codons 88-95 (YVNVNMGL) and 84-91 (LVVSYVNV) of the adr prototype core sequence, respectively. These findings support that the hypervariable region may be the $T$ cell recognition epitope.

The pre-C protein of 29 amino acid residues is highly hydrophobic, and acts as a "leader sequence" to engage the pre-C and core peptide into the membrane of the endoplasmic reticulum $(32,33)$. It has been shown that the secretory HBeAg peptide is derived from the cleavage of the pre-C and core peptide at its amino and carboxyl terminus after translocation into the endoplasmic reticulum $(32,33)$. Secretory $\mathrm{HBeAg}$ consists of a part of the $3^{\prime}$-end of the precore region ( 10 amino acid residues) and the majority of the core region (lacking only 34-36 amino acid residues at its carboxyl terminus) (34) (Fig. 1). Thus, secretory $\mathrm{HBeAg}$ contains a hypervariable region. The pre-C stop codon mutation was found only in patients who already had mutations in the hypervariable region of the core peptide (Table I) or after the appearance of a mutation in the core region (Fig. 4). It may be that the virus mutates to induce a stop codon at the 3'-end of the hydrophobic leader sequence to cease continuous secretion of the immunological target (modified core peptide), and to avoid the attack from lymphocytes. In this regard, it would appear of interest to test whether the in vitro killing activity of lymphocytes is effected by wild virus or mutant virus.

The question may be raised whether the mutations are a result of pressure from lymphocytes or whether they primarily evoke lymphocyte attack. The appearance of an amino acid substitution in the clustering region after start of elevation of serum ALT levels in one patient (Fig. 4) strongly supports the former possibility. We directly sequenced the amplified product and observed the change only in the dominant type virus. Thus the existence of a minor population having the mutation before the start of ALT elevation could not be totally excluded. We need further study to clarify the uncertain nature of the relationship between the initiations of attacks from CTL and the mutations in the core region.

The natural course of B-viral liver diseases is quite variable (26), and good prognostic markers are lacking. In this study, we analyzed the blood samples taken relatively early in the followup period in our patients (average $1.2 \mathrm{yr}$ from the start of follow-up). The absence of mutations in the clustering region was related to an uneventful course, and in contrast, the presence of such changes was associated with progressive B-viral liver disease. Thus, the most important clinical implication of our findings, perhaps, is that the presence of an amino acid substitution in the mutation clustering region might be used as an indicator of worsening of the disease. In fact, two patients in group B have already developed hepatocellular carcinoma.

\section{Acknowledgment}

We appreciate the critical review by Dr. Kunio Okuda.

\section{References}

1. Edgington, T. S., and F. V. Chisari. 1975. Immunological aspects of hepatitis B virus infection. Am. J. Med. Sci. 270:213-227.

2. Mondelli, M., G. M. Vergani, A. Alberti, D. Vergani, B. Portmann, A. L. W. F. Eddleston, and R. Williams. 1982. Specificity of lymphocytes cytotoxicity to autologous hepatocytes in chronic hepatitis B virus infection: evidence that $\mathrm{T}$ cells are directed against $\mathrm{HBV}$ core antigen expressed on hepatocytes. $J$. Immunol. 129:2773-2778.

3. Vento, S., J. E. Hegarty, A. Alberti, C. J. O'Brien, G. J. M. Alexander, A. L. W. F. Eddleston, and R. Williams. 1985. T lymphocytes sensitization to $\mathrm{HBcAg}$ and $\mathrm{T}$ cell-mediated unresponsiveness to $\mathrm{HBsAg}$ in hepatitis B virus-related chronic liver disease. Hepatology. 5:192-197.

4. Ferrari, C., A. Penna, T. Giuberci, M. J. Tong, E. Ribera, F. Fiaccadori, and F. V. Chisari. 1897. Intrahepatic, nucleocapsid antigen-specific $\mathrm{T}$ cell in chronic active hepatitis B. J. Immunol. 139:2050-2058.

5. Milich, D. R., J. L. Hughes, R. Houghten, A. McLachlan, and J. E. Jones. 1989. Functional identification of agretopic and epitopic residues within an HBcAg T cell determinant. J. Immunol. 143:3141-3147.

6. Tiollais, P., C. Pourcel, and A. Dejean. 1985. The hepatitis B virus. Nature (Lond.). 317:489-495.

7. Van Bleek, G. M., and S. G. Nathenson. 1990. Isolation of an endogenously processed immunodominant viral peptide from the class $\mathrm{I} \mathrm{H}-2 \mathrm{~K}^{\mathrm{b}}$ molecule. $\mathrm{Na}$ ture (Lond.). 348:213-216.

8. Rötzschke, O., K. Falk, K. Deres, H. Shild, M. Norda, J. Metzger, G. Jung, and H. G. Rammensee. 1990. Isolation and analysis of naturally processed viral peptides as recognized by cytotoxic T cells. Nature 348:252-254.

9. Saiki, R. K., S. Scharf, F. Faloona, K. B. Mullis, G. T. Horn, H. A. Erlich, and N. Arnheim. 1985. Enzymatic amplification of beta-globin genomic sequences and restriction site analysis for diagnosis of sickle cell anemia. Science (Wash. DC). 230:1350-1354.

10. Yokosuka, O., M. Omata, K. Hosoda, M. Tada, T. Ehata, and M. Ohto. 1991. Detection and direct sequencing of hepatitis B virus genome by DNA amplification method. Gastroenterology. 100:175-181.

11. Tada, M., M. Omata, and M. Ohto. 1990. Analysis of ras gene mutations in human hepatic malignant tumors by polymerase chain reaction and direct sequencing. Cancer Res. 50:1121-1124.

12. Kobayashi, M., and K. Koike. 1984. Complete nucleotide sequence of hepatitis B virus DNA of subtype adr and its conserved gene organization. Gene. 30:227-232.

13. Ono, Y., H. Onda, R. Sasada, K. Igarashi, Y. Sugino, and K. Nishioka. 1983. The complete nucleotide sequences of the cloned hepatitis B virus DNA: subtype adr and adw. Nucleic Acids Res. 11:1747-1757.

14. Fujiyama, A., A. Miyanohara, C. Nozaki, T. Yoneyama, N. Ohtomo, and 
K. Matsubara. 1983. Cloning and structural analyses of hepatitis B virus DNAs, subtype adr. Nucleic Acids Res. 11:4601-4610.

15. Roh, H., K. Kim, S. W. Hyun, and Y. S. Kim. 1989. The nucleotide sequence and reading frames of a mutant hepatitis B virus adr. Nucleic Acids Res. 17:2124-2124.

16. Okamoto, H., M. Imai, M. Shimozaki, Y. Hoshi, H. lizuka, B. Gotanda F. Tsuda, Y. Miyakawa, and M. Mayumi. 1986. Nucleotide sequence of a cloned hepatitis B virus genome, subtype ayr: comparison with genomes of the other three subtypes. J. Gen. Virol. 67:2305-2314.

17. Okamoto, H., F. Tsuda, H. Sakugawa, R. I. Sastrosoewignjo, M. Imai, Y. Miyakawa, and M. Mayumi. 1988. Typing hepatitis B virus by homology in nucleotide sequence: comparison of surface antigen subtypes. J. Gen. Virol. 69:2575-2583.

18. Cheng, S., R. Vogel, W. Ye, M. Blume, S. Lee, and P. Hung. 1988. The core gene of hepatitis B virus: subtype adw-2. Nucleic Acids Res. 16:8188.

19. Valenzuela, P., M. Quiroga, J. Zaldivar, P. Gray, and W. J. Rutter. 1980. The nucleotide sequence of the hepatitis $B$ viral genome and the identification of the major viral genes. In Animal Virus Genetics. B. N. Fields, R. Jaenish, and C. F. Fox, editors. ICN-UCLA Symp. Mol. Cell. Biol. 18:57-70.

20. Pasek, M., T. Goto, W. Gilbert, B. Zink, H. Schaller, P. MacKay, G. Leadbetter, and K. Murray. 1979. Hepatitis B virus genes and their expression in E. coli. Nature (Lond.). 282:575-579.

21. Galibert, F., E. Mandart, F. Fitoussi, P. Tiollais, and P. Charnay. 1979. Nucleotide sequences of the hepatitis B virus genome (subtype ayw) cloned in $E$. coli. Nature (Lond.). 281:646-650.

22. Bichko, V., D. Dreilina, P. Pushko, P. Pumpen, and E. Gren. 1985. Subtype ayw variant of hepatitis B virus. FEBS (Fed. Eur. Biochem. Soc.) Lett. 185:208-212.

23. Carman, W. F., M. R. Jacyna, S. Hadziyannis, P. Karayiannis, M. J. McGarvey, A. Makris, and H. C. Thomas. 1989. Mutation preventing formation of hepatitis B e antigen in patients with chronic hepatitis B infection. Lancet. ii: $588-591$.

24. Akahane, Y., T. Yamanaka, H. Suzuki, Y. Sugai, F. Tsuda, S. Yotsumoto S. Omi, H. Okamoto, Y. Miyakawa, and M. Mayumi. 1990. Chronic active hepatitis with hepatitis B virus DNA and antibody against $e$ antigen in the serum: disturbed synthesis and secretion of $e$ antigen from hepatocytes due to a point mutation in the precore region. Gastroenterology. 99:1113-1119.

25. Kosaka, Y., K. Takase, M. Kojima, M. Shimizu, K. Inoue, M. Yoshiba, S. Tanaka, Y. Akahane, H. Okamoto, F. Tuda, Y. Miyakawa, et al. 1991. Fulminant hepatitis B: induction by hepatitis B virus mutants defective in the precore region and incapable of encoding $e$ antigen. Gastroenterology. 100:1087-1094.

26. Hoofnagle, J. H. 1983. Chronic type B hepatitis. Gastroenterology. $84: 422-424$.

27. Hillis, W. D., A. Hillis, W. B. Bias, and W. G. Walker. 1977. Association of hepatitis B surface antigenemia with HLA locus B specificities. $N$. Engl. $J$. Med. 296:1310-1314.

28. Carman, W. F., A. R. Zanetti, P. Karayiannis, J. Waters, G. Manzillo, E. Tanzi, A. Zuckerman, and H. C. Thomas. 1990. Vaccine-induced escape mutant of hepatitis B virus. Lancet. 336:325-329.

29. Okamoto, H., M. Imai, M. Kametani, T. Nakamura, and M. Mayumi. 1987. Genomic heterogeneity of hepatitis B virus in a 54-year-old woman who contracted the infection through materno-fetal transmission. Jpn. J. Exp. Med. 57:231-236.

30. Milich, D. R., A. McLachlan, A. Moriarty, and G. B. Thornton. 1987. Immune response to hepatitis $B$ virus core antigen $(\mathrm{HBcAg})$ : localization of $T$ cell recognition sites within $\mathrm{HBcAg} / \mathrm{HBeAg}$. J. Immunol. 193:1223-1231.

31. Falk, K., O. Rötzschke, S. Stevanovic, G. Jung, and H. G. Rammensee. 1991. Allele-specific motifs revealed by sequencing of self-peptides eluted from MHC molecules. Nature (Lond.). 351:290-296.

32. Uy, A., V. Bruss, W. H. Gerlich, H. G. Kochel, and R. Thomssen. 1986 Precore sequence of hepatitis B e antigen in the serum. Virology. 155:89-96.

33. Standring, D. N., J. H. Ou, F. R. Masiarz, and W. J. Rutter. 1988. A signal peptide encoded within the precore region of hepatitis $B$ virus directs the secretion of a heterogeneous population of e antigens in Xenopus oocytes. Proc. Natl. Acad. Sci. USA. 85:8405-8409.

34. Takahashi, K., A. Machida, G. Funatsu, M. Nomura, S. Usuda, S. Aoyagi, K. Tachibana, H. Miyamoto, M. Imai, T. Nakamura, et al. 1983. Immunochemical structure of hepatitis B e antigen in the serum. J. Immunol. 130:2903-2907. 